\title{
Pb UPTAKE BY QUAIL GRASS (CELOSIA ARGENTEA) GROWN ON Pb - ACID BATTERY SOIL TREATED WITH STARCH STABILIZED ZERO-VALENT IRON NANOPARTICLES. \\ ${ }^{\mathrm{a}}$ Emina, Anwuli, ${ }^{\mathrm{a}^{*}}$ Okuo, James and ${ }^{\mathrm{b}}$ Anegbe, Bala.
}

${ }^{a}$ Environmental Analytical Research Laboratory, Department of Chemistry, University of Benin, Benin City. e-mail: james.okuo@uniben.edu

${ }^{b}$ Department of Basic and Industrial Chemistry, Western Delta University, P.M.B. 10, Oghara, Delta State. e-mail: balaanegbe@yahoo.com

*Corresponding author: james.okuo@uniben.edu

(Received:10th May, 2017; Accepted: 21st September, 2017)

\section{ABSTRACT}

\begin{abstract}
The effect of zero-valent iron nanoparticles (nZVI) on the physiology and uptake of heavy metals and nutrients in plants is crucial in the development of nanotechnology for the reclamation of contaminated soils. Zerovalent iron nanoparticles are able to immobilize heavy metals thereby reducing its bioavailability. Plant uptake experiment was thus used to evaluate the immobilizing potentials of starch stabilized zerovalent iron nanoparticles (S-nZVI) in the uptake of $\mathrm{Pb}$ by Celosia argentea grown on Pb-acid battery contaminated soil. Application of $1000 \mathrm{mg} / \mathrm{kg}$ of S-nZVI to the parent soil reduced bioavailable Pb in Celosia argentea (Quail grass). Celosia argentea grown on the starch stabilized zerovalent iron nanoparticles soil showed better tolerance to $\mathrm{Pb}$ than that grown on the parent soil. This was ascertained by the higher shoot and root biomass (dry weight matter). The concentration of iron was found to be higher in the shoots of Celosia argentea grown on the parent soil than for the treated soil. The higher translocation factor (TF) for iron in Celosia argentea (Quail grass) grown on the untreated soil might be one of the factors responsible for the observed trend. The TF for Pb was greater than one, an indication that Celosia argentea could be used in phytoremediation. The result from the pot experiment showed that $\mathrm{S}-\mathrm{nZVI}$ significantly reduced phytoavavilable $\mathrm{Pb}$.
\end{abstract}

Key words: Heavy metals; starch stabilized zero-valent iron nanoparticles; Celosia argentea; Phytoremediation

\section{INTRODUCTION}

Lead is one of the most widespread heavy metals in soils and groundwater. (Tangahu et al., 2011 and Zhao et al., 2009). Minute quantity of $\mathrm{Pb}$ can be very toxic to biotas (Zimmerman, 2010). The U.S. Environmental Protection Agency (USEPA) and Agency for Toxic Substances and Disease Registry (ATSDR) have ranked lead as the second most hazardous substances in the U.S. (ATSDR, 2005). Accumulated levels of these heavy metals could have a negative influence on the physiological procedures of the plant (Ioan et al., 2008; Moosavi and Seghatoleslami, 2013). Plants are able to uptake, translocate, and store toxic elements, whose chemical properties simulate those of essential elements. The roots are able to immobilize these heavy metals in the soil and groundwater through adsorption onto the roots or precipitation within the root zone (Tangahu et al., 2011). Plants therefore have the ability to absorb the bioavailable fractions of these heavy metals from the surrounding soil through their roots and translocating these heavy metals so absorbed into its edible tissues thus bioaccumulating these heavy metals in its tissue
(Rahman and Zaim, 2015; Tangahu et al., 2011).

The thermodynamic solubility of a contaminant containing mineral in the environment can directly influence the chemical reactivity, transport and ecotoxicology of the heavy metal ions since contaminant uptake and contaminant mobility of these heavy metals in natural systems occur typically through the solution phase (Kalembkiewicz and Soèo, 2005; Traina and Laperche, 1999). That is to say, for a heavy metal to be available for uptake by plants, it has to be present in the soil solution. This therefore means that ideally there exist a relationship between the concentration of the free metal ion activity in the soil solution and the level of heavy metal uptake by plant. The concentration of heavy metals is thus controlled by the dissolution and precipitation of discreet mineral phase (Traina and Laperche, 1999). Natural and synthetic amendments/additives such as phosphates, biochar, lignite, Fe and Mn oxides, Fe(II)sulphate, aluminosilicates, coal, flyash, clay minerals, microbes, organic compost, sulphate salts, compounds of sulphur, micro and nanoscale iron 
have been added to soils to alter soil chemistry. (Anegbe et al., 2014; Gaast et al., 2003; Gatma et al., 2005; Mench et al., 1998; Uzinger and Anton 2008; Weigand et al., 2003; Zubillaga et al., 2008). These additives are able to immobilize these heavy metals through adsorption or change in the redox state of these heavy metals thus effectively reducing the mobility, bioavailability and toxicity of the heavy metals in soils/sediments (Galdames et al., 2017; Wang et al., 2009; Wang et al., 2015).

In recent times, the use of zerovalent iron nanoparticles (especially the stabilized zerovalent iron nanoparticles) have received considerable attention and is preferred to other methods of immobilization because of their extremely large surface area, high reactivity and ability to diffuse and disperse in water and soils. These attributes enables the stabilized zerovalent iron nanoparticles to get to target contaminant for effective immobilization thus eliminating excessive input of the immobilizing agent and thus reducing cost (Prabu and Parthiban, 2013; Zhao et al., 2009; Zhang, 2003). Several literatures have reported huge success in the use of zerovalent iron nanoparticles in the immobilization of heavy metals (Gil- Díaz et al., 2013; Gueye et al., 2015; Xu et al., 2007; Zhao et al., 2009). Studies on its effect on plants is however still unclear and has not been given considerable attention (Li et al., 2015).

Chemical sequential extraction procedure has often been used to evaluate phytoavailable metal in nZVI treated soils (Gil - Díaz et al., 2014). The uptake of heavy metals by plants is however dependent on plant species and the physicochemical factors governing soil chemistry (Tangahu et al., 2011) and as such a chemical extraction though an important tool in estimating phytoavailable heavy metal may not be sufficient in evaluating the immobilizing effect of zerovalent nanoparticles in plants. This work therefore is an attempt at prognosis and prophylaxis on the reclamation of arable soils and would hence provide an insight into the immobilizing effects of zerovalent iron nanoparticles on $\mathrm{Pb}$ uptake and plant physiology using Celosia argentea as an indicator of the phytoavailable $\mathrm{Pb}$ in starch stabilized zerovalent iron nanoparticles treated soils.

\section{MATERIALS AND METHODS}

\section{Preparation of S-nZVI}

All reagents used in this study were all of analytical grade. The reduction method proposed by (Wang and Zhang, 1997) was used in preparing S-nZVI. Aqueous solutions were purged with nitrogen gas prior to synthesis and all the reactions were done in a $250 \mathrm{~mL}$ conical flask under nitrogen purge at ambient temperature. $1.62 \mathrm{~g}$ of iron (III) chloride hexahydrate was dissolved in $24 \mathrm{~mL}$ deionized water the ferric solution was then added drop wise through a syringe to a $6 \mathrm{~mL}$ solution of starch under simultaneous stirring to yield a $0.2 \% \mathrm{w} / \mathrm{v}$ of starch concentration. $0.80 \mathrm{~g}$ of sodium borohydride was dissolved in $50 \mathrm{~mL}$ nitrogen purged deionized water and was thereafter added drop wise through a syringe to the iron (III) chloride/starch complex under vigorous stirring. Slowly the solution turned black and was stirred for five minutes after all the sodium borohydride had been added. The black particles were collected using a magnet, washed via centrifugation with $50 \mathrm{~mL}$ of nitrogen saturated deionized water followed with washing in three portions of $25 \mathrm{~mL}$ absolute ethanol and then oven dried at a temperature of $60^{\circ} \mathrm{C}$ for 12 hours. This procedure was repeated several times to obtain about $1.5 \mathrm{~g}$ of S-nZVI. Bare zerovalent iron nanoparticles (ZVI) were synthesized likewise but in the absence of starch $\left(\mathrm{FeCl}_{3}\right.$ solution was prepared in a mixture of $24 \mathrm{~mL}$ ethanol and $6 \mathrm{ml}$ deionized water to prevent rapid oxidation). (Fig. 1)

\section{Treatment of Soil with Starch Stabilized Zerovalent Iron Nanoparticles}

Soil from a $\mathrm{Pb}$ battery manufacturing site was treated with S-nZVI. A gram of zerovalent iron nanoparticles was added to $999 \mathrm{~g}$ of the parent soil (a dosage level of $0.1 \% \mathrm{~S}-\mathrm{nZVI}$ ). The soil and nanoparticles were thoroughly mixed followed by the addition of $100 \mathrm{~mL}$ of deionized water. The soil was thoroughly mixed again to ensure uniformity and proper dispersion of the nanoparticles. The soil was then incubated for 3weeks. The parent soil and treated soils were then used to evaluate the plant uptake of heavy metals. 


\section{Planting}

Two weeks old uniform seedlings of Celosia argentea from Obasanjo Farms Ota were transplanted into $200 \mathrm{~g}$ of parent and $0.1 \%$ starch stabilized zerovalent iron nanoparticles treated soils. The experiment was arranged in completely randomized design with five replications for each soil. The plants were harvested after two weeks. They were first washed in tap water to remove sand particles and then rinsed in distilled water. The shoots were thereafter separated from the roots.

\section{Digestion of Plant Samples}

The plant samples were air dried to a constant weight after which they were ground into powder. Plant samples were first pre-digested in concentrated $\mathrm{HNO}_{3}$ followed by digestion in a 3:2 diacid mixture of $\mathrm{HNO}_{3}$ and $\mathrm{HClO}_{4}$. Deionized water was added followed by filtration with Whatmann No 1 filter paper. The digestate was then diluted appropriately and analyzed for mineral uptake using AAS Buck scientific VGP 210 model (Deo et al., 2011).

\section{RESULTS AND DISCUSSION \\ Characterization of Starch Stabilized Zerovalent Iron Nanoparticles}

The crystallographic analysis of S-nZVI used in this study was performed by powder $\mathrm{x}$-ray diffraction using X- ray diffractometer (Philip's $\mathrm{X}$ 'pert Pro, $\mathrm{UK})$ with $\mathrm{Cu} \mathrm{K} \alpha$ radiation $(\lambda=0.154)$. The diffraction pattern obtained over a $2 \theta$ range of $25-70^{\circ}$ is shown in Fig. 1. The diffraction pattern showed that of an amorphous phase of $\mathrm{Fe}$ and the characteristic broad peak at 20 of about 45 showed that of zerovalent iron (Rashmi et al., 2013; Selvarani and Prema, 2012; Sun et al., 2006). Iron oxide peaks as seen in the spectra of bare ZVI (1) and (2) were not noticed in XRD spectra of S-nZVI. Same results were obtained by Selvarani and Prema, (2010), using starch stabilized formation of iron oxide $(\mathrm{FeO})$. Other related works have however reported that there was no appearance of oxide / hydroxide shell formation in the outer surfaces of the bare zerovalent iron nanoparticles (Rashmi et al., 2013; Yuvakkumar, 2011). Since both zerovalent iron nanoparticles were synthesized in the same manner, it is most likely that the starch used in the synthesis of the modified zerovalent iron nanoparticles protected the zerovalent iron nanoparticles from rapid oxidation and the synthesized S-nZVI was predominantly in its zero-valent state. The average particle size of SnZVI was $9.58 \mathrm{~nm}$ as calculated from Debye Scherer formula in equation 1 (Huang and Tang, 2005).

$\mathrm{d}=\frac{\mathrm{K \lambda}}{\beta \cos \theta}$

Where $\mathrm{d}$ is the particle size of the crystal, $\mathrm{k}$ is Scherer constant (0.9), $\lambda$ is the $\mathrm{X}$ - ray wavelength $(0.15406 \mathrm{~nm}), \beta$ is the line broadening in radian obtained from width at half maximum, and $\theta$ is the Bragg diffraction angle of the XRD diffraction pattern.

The magnetic properties as obtained using physical property measuring system PPMS is shown in Fig. 2. The hyteresis loop shows that the particles were superparamagnetic (Faraji et al., 2010; Krajewski et al., 2015). As extrapolated from the magnetization curve, the synthesized starch stabilized zerovalent iron nanoparticles had a coercivity value of 1628 Oe and a saturation magnetization $\left(M_{s}\right)$ of $27 \mathrm{emu} / \mathrm{g}$ which is lower than that of bulk iron which has a $\mathrm{M}_{\mathrm{s}}$ of $92 \mathrm{emu} / \mathrm{g}$ (Alagiri etal., 2015; Vecchia et al., 2008). 


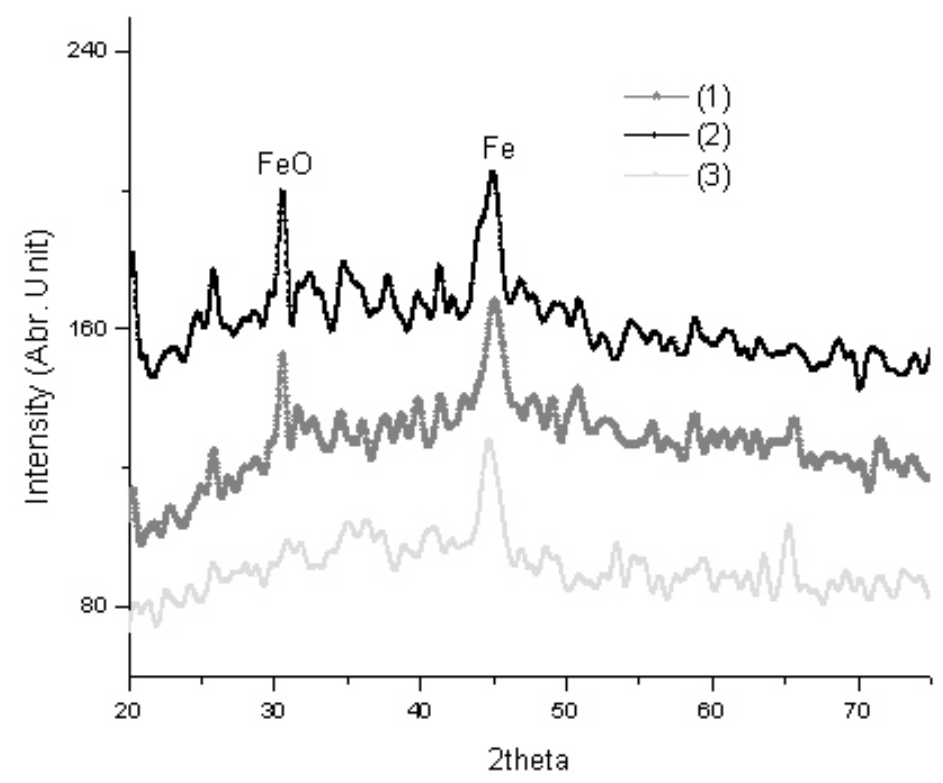

Fig. 1: X-Ray Diffraction Pattern of nZVI and Starch Stabilized Zerovalent Iron Nanoparticles (1\&2=nZVI, 3= S-nZVI) .

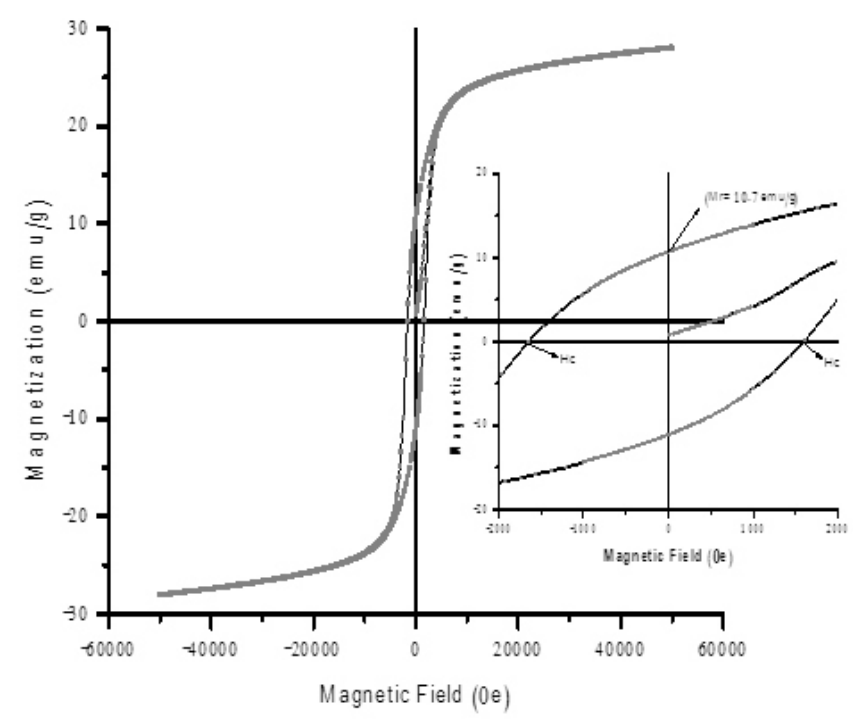

Fig. 2: Magnetic Hysteresis Loop of S-nZVI under Magnetic Field upto 50 K Oe at 300 K. Hyteresis Parameters such as Saturation Magnetization, Magnetization Coercivity and Remenance Magnetization are shown.

Table 1: Selected Physicochemical Properties of Pb Acid Battery Soil.

\begin{tabular}{lccccccccc}
\hline $\mathbf{p H}$ & $\begin{array}{c}\text { Organic } \\
\text { carbon }(\%)\end{array}$ & $\begin{array}{c}\text { Organic } \\
\text { matter }(\%)\end{array}$ & Sand (\%) & Clay (\%) & Silt (\%) & $\begin{array}{c}\text { CEC } \\
(\mathrm{meq} / 100 \mathrm{~g})\end{array}$ & $\begin{array}{c}\mathrm{Pb} \\
(\mathrm{mg} / \mathrm{kg})\end{array}$ & $\begin{array}{c}\mathrm{Zn} \\
(\mathrm{mg} / \mathrm{kg})\end{array}$ & $\mathrm{Fe}(\mathrm{mg} / \mathrm{kg})$ \\
\hline $4.20 \pm 0.10$ & $2.7332 \pm 0.28$ & $4.725 \pm 0.55$ & $73.40 \pm 0.98$ & $23.60 \pm 0.45$ & $3.00 \pm 0.33$ & $5.23 \pm 0.04$ & $4980 \pm 20.50$ & $100 \pm 2.00$ & $15249.50 \pm 72.56$ \\
\hline
\end{tabular}

Effect of Starch Stabilized Zerovalent Iron Nanoparticles on the Physiology of Celosia Argentea

Celosia argentea grown in parent and treated soils both showed the toxic effect of $\mathrm{Pb}$ as there was withering of leaves. However, Celosia argentea grown in the starch stabilized zero iron nanoparticles treated soil showed better tolerance to the $\mathrm{Pb}$ contaminated soil than that grown on the untreated soil. This can be ascertained by the lower rate of withering and higher plant biomass (dry weight matter) as observed in Tables 2 and 3. The little withering observed in the treated soil is as a result of the extremely high concentration of $\mathrm{Pb}$ in the soil and therefore a higher dose of zerovalent iron nanoparticles would be needed to reduce the phytoavailable $\mathrm{Pb}$ to concentrations that are not phytoxic. 
The tolerance index, TI based on the dry weight of plant is an indicator of the toxic effect of metals on plants growing in heavy metal contaminated soil. The equation for the calculation TI for heavy metals is shown in equation 2 (Ebrahimi, 2013).

$T I=\frac{\text { dry weight of the plant grown in heavy metal soil }}{d r y \text { weight of plant in control }}$

Consequently, in this study the TI indicator for toxic effect of zerovalent iron nanoparticles in heavy metal soil is given by

$T I=\frac{d r y \text { weight of the plant grown } S-n Z V I \text { soil }}{d r y \text { weight of plant in control }}$
Where the control is the heavy metal soil without starch stabilized zerovalent iron nanoparticles.

While $\mathrm{TI}$ for $\mathrm{Pb}$ in the root increased from 0.28 to 0.34 in treated soil that of the shoots increased from 0.27 to 0.32 . TI for starch stabilized zerovalent iron nanoparticles in heavy metal soil for root and shoot were 1.24 and 1.15 respectively. These values are greater than 1 , an indication that the application of starch stabilized zerovalent iron nanoparticles did not have a negative effect on the plant physiology but rather a positive effect. Plant turgidity is a term that is used to refer to the ability of plants to remain upright in the soil. Celosia argentea grown on the treated soil also showed greater turgid strength as shown Fig. 3.

Table 2: Effect of S-nZVI on Leaf Withering

\begin{tabular}{|c|c|c|c|c|c|c|c|c|c|c|}
\hline \multicolumn{11}{|c|}{ Number of withered leaves (dropped leaves) } \\
\hline \multirow[t]{2}{*}{ Day } & \multicolumn{5}{|c|}{ Parent soil } & \multicolumn{5}{|c|}{$0.1 \%$ treated soil } \\
\hline & Pot 1 & Pot 2 & Pot 3 & Pot 4 & Pot 5 & Pot 1 & Pot 2 & Pot 3 & Pot 4 & Pot 5 \\
\hline 1 & 0 & 0 & 0 & 0 & 0 & 0 & 0 & 0 & 0 & 0 \\
\hline 2 & 0 & 0 & 0 & 0 & 0 & 0 & 0 & 0 & 0 & 0 \\
\hline 3 & 1 & 2 & 1 & 2 & 1 & 0 & 0 & 0 & 0 & 0 \\
\hline 4 & 0 & 0 & 0 & 0 & 1 & 0 & 1 & 1 & 1 & 0 \\
\hline 5 & 0 & 0 & 0 & 0 & 0 & 0 & 0 & 0 & 0 & 1 \\
\hline 6 & 1 & 1 & 1 & 0 & 1 & 1 & 0 & 0 & 0 & 0 \\
\hline 7 & 1 & 1 & 0 & 1 & 0 & 0 & 0 & 0 & 0 & 0 \\
\hline 8 & 0 & 0 & 0 & 0 & 0 & 0 & 0 & 0 & 0 & 0 \\
\hline 9 & 0 & 0 & 0 & 0 & 0 & 0 & 0 & 0 & 0 & 0 \\
\hline 10 & 0 & 0 & 0 & 0 & 0 & 0 & 1 & 0 & 0 & 0 \\
\hline 11 & 0 & 0 & 0 & 0 & 0 & 0 & 0 & 0 & 0 & 0 \\
\hline 12 & 0 & 0 & 0 & 0 & 0 & 0 & 0 & 0 & 0 & 0 \\
\hline 13 & 0 & 0 & 0 & 0 & 0 & 0 & 0 & 0 & 0 & 0 \\
\hline 14 & 0 & 0 & 0 & 0 & 0 & 0 & 0 & 0 & 0 & 0 \\
\hline Total & 3 & 4 & 2 & 3 & 3 & 1 & 2 & 1 & 1 & 1 \\
\hline
\end{tabular}

Table 3: Dry Weight (g) of Plants (Mean dry weight of seedling in distilled water (control): root $0.25 \mathrm{~g}$, shoot $0.75 \mathrm{~g}$ )

\begin{tabular}{|c|c|c|c|c|c|c|}
\hline $\begin{array}{l}\text { Treatment levels of S- } \\
\text { nZVI }(\%)\end{array}$ & $\begin{array}{l}\text { Dry weight of } \\
\text { Root }\end{array}$ & $\begin{array}{l}\text { Dry weight of } \\
\text { Shoot }\end{array}$ & $\begin{array}{c}\text { TI } \\
\text { (Root) }\end{array}$ & $\begin{array}{c}\text { TI } \\
\text { (Shoot) }\end{array}$ & $\begin{array}{l}\mathrm{TI}_{\mathrm{S}-\mathrm{nZVI}} \\
\text { (Root) }\end{array}$ & $\begin{array}{l}\text { TI }{ }_{\text {S-nZVI }} \\
\text { (Shoot) }\end{array}$ \\
\hline 0 & $0.070 \pm 0.008$ & $0.207 \pm 0.050$ & 0.28 & 0.27 & - & - \\
\hline 0.1 & $0.087 \pm 0.006$ & $0.240 \pm 0.072$ & 0.34 & 0.32 & 1.24 & 1.15 \\
\hline
\end{tabular}

Fig. 3: Celosia Argentea Grown on Treated Soil (A) and Parent Soil (B) 
From the results, the phytoxic symptoms observed in the plants is as a result of the extremely high concentration of the $\mathrm{Pb}$ in the soils used rather than the application of zerovalent iron nanoparticles.

\section{Heavy Metal Uptake}

The uptake of $\mathrm{Pb}$ is quite high in Celosia argentea grown on both the parent and treated soil. However, the application of zerovalent iron nanoparticles to the soil significantly reduced the uptake of $\mathrm{Pb}$ grown on the treated soil. In the shoots, $\mathrm{Pb}$ uptake was reduced from 147.78 $\mathrm{mg} / \mathrm{kg}$ to $89.84 \mathrm{mg} / \mathrm{kg}$ after the application of $1000 \mathrm{mg} / \mathrm{kg}$ starch modified zerovalent iron nanoparticles. In the roots, $\mathrm{Pb}$ uptake was reduced from $146.31 \mathrm{mg} / \mathrm{kg}$ to $88.07 \mathrm{mg} / \mathrm{kg}$. The ability of roots to transfer heavy metals to the shoots can be explained by a translocation factor or transfer factor (TF). It is given as the ratio of metal concentration in plant shoot to that in the root. The translocation factor for $\mathrm{Pb}$ in both parent and treated soils were 1.01 and 1.02 respectively. A translocation factor that is equal to 1 is an indication that the plant is a potential phytoaccumulator (Ebrahimi et al., 2007; Aiyesanmi, 2012). These values therefore indicate that Celosia argentea may be a good hyperaccumulator of $\mathrm{Pb}$ in phytoremediation.

The application of zerovalent iron nanoparticles to the soil significantly reduced the uptake of $\mathrm{Zn}$ in Celosia argentea grown on the treated soil in both shoots and roots. The translocation factor for $\mathrm{Zn}$ in plants grown on parent and treated soils were $1.35 \pm 0.33$ and $1.14 \pm 0.31$ respectively. These values again indicate that Celosia argentea may be a good hyperaccumulator of $\mathrm{Zn}$ in phytoremediation. However, the application of zerovalent iron nanoparticles may lead to $\mathrm{Zn}$ deficiency since it is an essential nutrient. Though Zn deficiency was not established in this report as can be seen from the high concentration of $\mathrm{Zn}$ in Celosia argentea.

Nanoparticles can be taken up by the root and transported to the above parts of the plant or may adhere to the roots depending on the anatomy of the plant, composition, size and shape of nanoparticles (Nedecky et al., 2017). Although total heavy metal may not always be used in predicting bioavailable metals (Anarwar, 2008; Zimmerman and Weindorf, 2010), most research works have however reported an increase in uptake of metals with increase in metal concentration (Intawongse and Dean, 2006; Nouri et a., 2009; Orhue and Ekhomun, 2010). The addition of S-nZVI to parent soil would increase the total $\mathrm{Fe}$ concentration and thus likely increase uptake in plant. The level of Fe uptake in the roots was slightly higher in Celosia argentea grown on the untreated soil. Conversely in the shoots, the level of $\mathrm{Fe}$ was reduced from 953.64 $\mathrm{mg} / \mathrm{kg}$ in the parent soil to $602.33 \mathrm{mg} / \mathrm{kg}$ in the treated soil despite the addition of Fe. This is probably due to higher translocation factor (TF) for iron in Celosia argentea grown on untreated soil. Since uniform seedlings were collected from the same source, the obviously lower concentration of $\mathrm{Fe}$ in the shoots and hence lower TF of plants grown on treated soil can be attributed to change in the surface chemistry of the soil and root zone owing to the presence S-nZVI (Nedecky et al., 2017). The lower TF is an indication that Celosia argentea may not have the internal detoxification mechanism to tolerate an eventual phytotoxicity of Fe nanoparticles (Nouri et al., 2009). The above observations show that iron nanoparticles are more likely to adsorb to the root zone and may not be easily translocated to the shoots. It is also an indication that the addition of S-nZVI may not have significantly increased leachable $\mathrm{Fe}$ (phytoavailable Fe).

Table 4: Heavy Metal Uptake (mg/kg)

\begin{tabular}{lcccccc}
\hline & \multicolumn{3}{c}{ Parent soil } & \multicolumn{3}{c}{ Treated soil } \\
\hline & Root & Shoot & TF & Root & Shoot & TF \\
\hline $\mathrm{Pb}$ & $146.31 \pm 2.67$ & $147.78 \pm 13.10$ & 1.01 & $88.04 \pm 1.99$ & $89.84 \pm 1.14$ & 1.02 \\
$\mathrm{Zn}$ & $605.44 \pm 172.50$ & $726.41 \pm 49.02$ & 1.31 & $534.76 \pm 33.79$ & $538.24 \pm 20.67$ & 1.14 \\
$\mathrm{Fe}$ & $1773 \pm 20.50$ & $953.64 \pm 67.54$ & 0.46 & $1800 \pm 44.11$ & $602.33 \pm 77.32$ & 0.33 \\
\hline
\end{tabular}


The bioconcentration factor shown in equations 4 and 5 is used in classifying plants as either bioaccumulators or excluders. A bioaccumulator has BCF values $>1$ while an excluder plant has $\mathrm{BCF}$ values $<1$ (Ebrahimi, 2013). The results show that Celosia argentea is an excluder of $\mathrm{Pb}$ and iron and a bioaccumulator of $\mathrm{Zn}$. The application of S-nZVI reduced the ability of Celosia argentea to function as either an excluder or a bioaccumulator.

$$
\begin{aligned}
& B C F_{\text {root }}=\frac{\left(C_{\text {root }}\right)}{\left(C_{\text {soil }}\right)} \\
& B C F_{\text {shoot }}=\frac{\left(C_{\text {shoot }}\right)}{\left(C_{\text {soil }}\right)}
\end{aligned}
$$

Where $\mathrm{C}_{\text {root }}$ and $\mathrm{C}_{\text {shoot }}$ are the metal concentration in the roots and shoots respectively and $\mathrm{C}_{\text {soil }}$ is the metal concentration in the soil.

Table 5: Bioconcentration Factor of Celosia argentea

\begin{tabular}{ccccc}
\hline Metal & \multicolumn{2}{c}{ Parent soil } & \multicolumn{2}{c}{ Treated Soil } \\
\hline & $\mathrm{BCF}_{\text {root }}$ & $\mathrm{BCF}_{\text {shoot }}$ & $\mathrm{BCF}_{\text {root }}$ & $\mathrm{BCF}_{\text {shoot }}$ \\
\hline $\mathrm{Pb}$ & 0.029 & 0.030 & 0.018 & 0.018 \\
$\mathrm{Zn}$ & 6.054 & 7.264 & 5.3476 & 5.382 \\
$\mathrm{Fe}$ & 0.110 & 0.062 & 0.118 & 0.039 \\
\hline
\end{tabular}

\section{CONCLUSION}

Starch stabilized zerovalent iron nanoparticles was able to immobilize phytoavailable $\mathrm{Pb}$ and $\mathrm{Zn}$ in lead-acid battery soil. It was ecofriendly and had a positive effect on the physiology of Celosia argentea. The use of zerovalent iron nanoparticles may create a means of reclaiming arable soil if the immobilization of essential nutrients can be controlled.

\section{REFERENCES}

Aiyesanmi, A.F. Okoronkwo, A.E. and Sunday, O.M. (2012). Lead accumulation in Siam weed (Chromolaena odorata and waterleaf Talinum triangulare. Potential phytoremediators. Arch Sci. Res. 4 (1): 360 371.

Alagiri, M., Muthamizhchelvan, C., Ponnusamy, S. (2015). Synthesis of Iron Nanowires and its Magnetic Properties. International Journal of ChemTech. Research. 7(2):16121615.

Anawar, H.M., Garcia-Sanchez, A. and SantaRegina, I. (2008). Evaluation of various chemical extraction methods to estimate plant-available arsenic in mine soils. Chemosphere 70: 1459-1467.

Anegbe, B., Okuo, J.M., Ewekay, E.O. and Ogbeifun, D.E. (2014). Fractionation of lead-acid battery soil amended with biochar. Bayero J. of Pure and Appli. Sci. 7(2): 36-43

ATSDR: Agency for Toxic Substances and
Disease Registry, U.S. Department of Health and Human Services (2005). "CERCLA Priority List of Hazardous

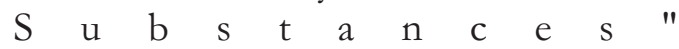
website:http://www.atsdr.cdc.gov/cercla /05list.html.

Deo, B., Nahak, G. and Sahu, R.K. (2011). Studies on the uptake of heavy metals by selected plant species growing on coal mine spoils in sub tropical regions of India. Journal of American science 7 (1): 26-34

Ebrahimi, M. (2013). Effect of EDTA application on heavy metals uptake and germination of Echinochloa crus galii(L) Beave in contaminated soil. Intl Agriculture Crop Sci. 6 (4): 197-202.

Faraji, M., Yamini, Y. and Rezaee, M. (2010). Magnetic Nanoparticles Synthesis, Stabilization and Application. J. Iran. Chem. Soc., 7(1):1-37.

Gaast, N.G, P.C., Ruiter, P. and Romkens, R.W. (2003). In situ immobilization of $\mathrm{Cd}$ and Zn polluted soils with cement and heated clay.ConSoil 2003 Gent Belgium Proceedings: 2229-2232.

Gatma, E., Mwinyija, M. and Killham, K. (2005). Assesment of pulverized fly ash (PFA) as an ameliorant of lead contaminated soils. Am. J.Environ. Sci. 1(3): 230-238.

Galdames, A., Mendoza, A., Orueta, M., Soto, García, I.S., Sánchez, M., Virto, I. and Vilas, J.L (2017). Development of new remediation technologies for 
contaminated soils based on the application of zero- valent iron nanoparticles and bioremediation with compost. Res. Eff. Tech 3: 166-176.

Gil - Díaz, M., Prez-Sanz, A., Vicente, M.A. and Lobo, C.M. (2013). Immobilization of $\mathrm{Pb}$ and $\mathrm{Zn}$ using stabilized iron nanoparticles: effects on soil properties. Clean-Soil, Air, Water, 42 (12): 1776-1784.

Gil - Díaz, M., Alonso, J., Rodriguez-Valdés, E., Pinilla, P. and Lobo, M.C. (2014). Reducing the Mobility of Arsenic in Brownfield Soil Using Stabilized ZeroValent Iron Nanoparticles. Environ. Sci. Health, 49 (12): 1361- 1369.

Gueye, M.T. Petrucci, E. and Palma, .L. (2015). Chemical reduction of hexavalent chromium vi soil slurry by Nanozerovalent iron, chem. Eng. Tra.1 43: 655- 660.

Huang, W. and Tang, X. (2005). Preparation, structure and magnetic properties of mesoporous magnetite hollow spheres, Journal of Colloid and Interface Science, 281 (2): 432-436.

Ioan, S., Cosma, C., Todică, M., Bolboacă, S.D. and Jäntschi, L. (2008). Analysis of Soil Heavy Metal Pollution and Pattern in Central Transylvania. Int JMolSci. 9(4): 434-453.

Intawongse, M. and Dean, J. R. (2006). Uptake of heavy metals by vegetable plants grown on contaminated soil and their bioavaibility in human gastrointestinal tract. J. Food Addictives \& contaminants 23 (1):36-48

Kalembkiewicz, J. and Soèo, E. (2005). Investigation of chemical fractions of $\mathrm{Cr}$ in soil. Polish Journal of Environmental Studies, 14 (5): 593-598.

Krajewski, M., Lin, W.E., Lin, H.M., Brozozka, K., Lewinska, S., Nedelko, N., SlawkaWaniewka, A., Borysiuk, J. and Wasik, D. (2015). Structural and magnetic properties of iron nanowires and nanoparticles fabricated through a reduction reaction. Beilstein J. Nanotechnol 6:1652-1660.

Li, X., Yang, Y., Gao, B., and Zhang, M. (2015). Stimulation of Peanut Seedling Development and Growth By Iron Nanoparticles at Low Concentrations. Plos ONE, 10 (4), e0122884. http://doi.org/10.1371/journal.pone.01
22884

Mench, M. J., Vangroensveld, J., Leep, N.M., Edwards, R. (1998). Physicochemical aspects and efficiency of trace element immobilization by soil amendment in Vangroensveld J., Cunningham, S.D (eds): metal contaminated soils. Springer, Berlin, pp 151-182.

Moosavi, S.G. and Seghatoleslami, M. J. (2013). Phytoremediation: A review. $A d v$. Agric.Biol. 1(1): 5-11.

Nedecky, B.R., Krystofova, O., Nejd, L. and Adam, V. (2017). Nanoparticles based on essential metals and their phytotoxicity. $J$. Nanobiotech 15:33

Nouri, J., Khorasani, N, Lorestani, B., Karami, M, Hassani, A.H. and Yousefi, N. (2009). Accumulation of heavy metals in soil and uptake by plant species with phytoremediation potentials. Environ Earth Sci $59: 315$. https://doi.org/10.1007/s12665-0090028-2

Orhue, E.R. and Ekhomun, (2010). Chromium Effects on Early Growth of Water Leaf (Talinum Triangulare)in an Ultisol. American- Eurasian J.Agric \& Environ.Sci. 7(5):586-590

Prabu, D. and Parthiban, R. (2013). Synthesis and Characterization of nanoscale zerovalent iron (NZVI) nanoparticles for environmental remediation. Asian J. Pharm. Tech. 13(4): 181-184.

Rahman, H. A. and Zaim, F.A. (2015). Concentration Level of Heavy Metals in Soil at Vegetables Areas in Kota Bharu, Kelantan, Malaysia. Int.J. Environ. Sci. and Dev. 6(11): 843-848.

Rashmi, S.H., Madhu, G.M., Kittur, A.A. and Suresh, R. (2013). Synthesis, characterization and application of zerovalent iron nanoparticles for the removal of toxic metal hexavalent chromium from aqueous solution. Int.J. of current engineering and technology. 37-42.

Selvarani, M. and Prema, D. (2012). Removal of toxic metal hexavalent chromium from aqueous solution using starch stabilized nanoscale zerovalent iron as adsorbent: Equilibrium and kinetics. Int. J. Environ.Sci. 2(4): 1962-1975. 
Sun, Y.P., Li, X., Cao, S., Zhang, W. and Wang, P.H. (2006). Characterization of zerovalent iron nanoparticles. Advances in Colloid and Interface Science 120 (2006) 47-56.

Tangahu, V.B., Abdullah, S.R.S., Basri, H., Idris, M. Anuar, N. and Mukhlisin, M. (2011). A review of heavy metal ( $\mathrm{As}, \mathrm{Pb}$ and $\mathrm{Hg}$ ) uptake by plants through phytoremediation. Int. J. Chem. Eng. 21:131.

Traina. S.J. and Laperche, V. (1999). Contaminant bioavailability in soils, sediments and aquatic environments. Pros Natl Acad Sci. 96 (7): 3365-3371.

Uzinger, N. and Anton, A. (2008). Chemical stabilization of heavy metals on contaminated soils by lignite. Cereal research communication. 36:1911-1914.

Vecchia, E.D., Coisson, M., Appino, C., Vinai, F. and Sethi. R. (2008). Magnetic Characterization and Interaction Modelling of Zerovalent Iron Nanoparticles for the Remediation of Contaminated Aquifers. J.Nanosci. and Nanotech. 9:1-9.

Wang, L.Q., Luo, L., Ma, Y.B., Wei, D.P. and Hua, L. (2009). In situ immobilization remediation of heavy metals-containing soils: a review. Ying Yong Sheng Tai Xue Bao 20 (5): 1214-22

Wang, J., Li, T. and Zhou, C. (2015). Physicochemical studies toward the removal of $\mathrm{Zn}$ (ii) and $\mathrm{Pb}$ (ii) ions through adsorption on montorillonite- supported zerovalent iron nanoparticles. Rsc. Adv. 15: 29859-29871.
Wang, C.B. and Zhang, W.X. (1997). Synthesizing nanoscale iron particles for rapid and complete dechlorination of TCE and PCBs, Environ. Sci. Technol.31: 2154 - 2156.

Weigand, H., Muller, S. and Marb, C. (2003). Chemical immobilization of arsenic and chromium in contaminated soil by iron (II) sulphate ConSoil 2003.12-16 May 2003.Gent, Belgium, Proceedings 21852193.

Xu, Y.H. and Zhao, D.Y. (2007). Reductive immobilization of chromate in water and soil using stabilized iron nanoparticles. Water Res. 41: 43-50.

Zhang, W. (2003). Nanoscale iron particles for environmental remediation: an overview. J. nanoparticles research 5: 323-332.

Zhao, D., Xiong, Z., Barnet, M., Lui, R., Harper, W.F. and $\mathrm{He}, \mathrm{F} .(2009)$. In situ immobilization of metals in contaminated sites using stabilized iron phosphate nanoparticles. US patent 7581902 . http://www.freepatentsonline.com/ 7581902.html

Zimmerman, A.J. and Weindorf, D.C. (2010). Heavy metal and trace analysis in soil by sequential extraction: A review of procedures. International Journal of Analytical Chemistry volume 2010, Article ID 387803, 7 pages http://dx.doi:10.1155/2010/387803.

Zubillaga, M.S., Bressan, E. and Lavdo, R.S. (2008). Heavy metal mobility in polluted soils: Effect of treatments. American Journal of Environmental Sciences. 4(6): 620624. 